\title{
Nuclear terrorism
}

\author{
Ira Helfand, Lachlan Forrow, Jaya Tiwari
}

Three members of International Physicians for the Prevention of Nuclear War and Physicians for Social Responsibility discuss the threat of nuclear terrorism and conclude that the only effective way to tackle it is to abolish nuclear weapons

Cooley Dickinson Hospital,

30 Locust Street

Northampton,

MA 01061-5001,

USA

Ira Helfand

chief, emergency

medicine section

Beth Israel

Deaconess Medical

Center, Harvard

Medical School,

Boston, MA USA

Lachlan Forrow

associate professor of

medicine

Center for Global

Security and

Health, Physicians

for Social

Responsibility,

Washington, DC

20009, USA

Jaya Tiwari

research director

Correspondence to:

Ira Helfand

ihelfand@igc.org

BMJ 2002;324:356-9
The attack on the World Trade Center in New York clearly showed that there are terrorists who are willing to inflict civilian casualties on the scale that would be expected with the use of a weapon of mass destruction. In this article we consider the form that nuclear terrorism could take and estimate the casualties that would occur if a nuclear bomb the size of that dropped on Hiroshima was detonated in a large urban area. The enormous casualties to be expected from such an attack argue strongly for a strategy of primary prevention.

\section{Nuclear power plants and "dirty bombs"}

Nuclear terrorism might take several forms. An attack on a nuclear power plant or other nuclear installation could result in a massive release of radioactive material. Despite initial statements by the US Nuclear Regulatory Commission that commercial power plants could withstand an aircraft crashing into them, it seems likely these plants are highly vulnerable. As early as 1982 a study by the Argonne National Laboratory of the US Department of Energy found that, if a jet aircraft crashed into a nuclear reactor and only $1 \%$ of its fuel ignited after impact, the resulting explosion could compromise the integrity of the containment building, with possible release of radioactive material. ${ }^{1}$ In the aftermath of 11 September, David Kyd, spokesman for the International Atomic Energy Agency, confirmed this view, stating: "[Reactors] are built to withstand impacts, but not that of a wide bodied passenger jet full of fuel.... These are vulnerable targets, and the consequences of a direct hit could be catastrophic" (Moneyline, CNN, 18 Sep 2001).

In addition to the reactors themselves, nuclear power plants harbour enormous quantities of radioactive materials in spent fuel pools. On average these spent fuel pools contain five times as much radioactive material as the reactor core, and they are housed in simple corrugated steel buildings even more vulnerable to attack than the reactor containment buildings. ${ }^{2}$ The vulnerability of nuclear power plants is highlighted by reports that $47 \%$ of US nuclear power plants failed to repel mock terrorist attacks conducted by the Nuclear Regulatory Commission during the 1990s. ${ }^{3}$ The results of an attack on either a reactor or a spent fuel pool could equal or exceed the effects of the 1986 Chernobyl disaster, which led to 30 acute deaths from radiation sickness, at least 1800 excess cases of childhood thyroid cancer, the evacuation of 100000 people, and the radioactive contamination of vast tracts of land in several countries (figure). ${ }^{4}$

Terrorists could also attack a city with a "dirty bomb" in which radioactive material is dispersed by conventional explosives. The Nuclear Regulatory Commission has estimated that such an attack could cause more than 2000 immediate and long term

\section{Summary points}

In the aftermath of 11 September 2001 nuclear terrorism has emerged as a real threat

Nuclear terrorism could take several forms, from an attack on nuclear power plants and reactors to the detonation of a nuclear bomb in an urban area

The international community urgently needs to expand its efforts to secure existing stockpiles of nuclear weapons and materials, particularly in Russia, Pakistan, and India

The elimination of nuclear weapons should be high on the global public health agenda

deaths and billions of dollars in property damage if a cask of spent fuel rods were dispersed in Manhattan at midday. $^{5}$

The ultimate nightmare remains an attack involving a nuclear explosion in a densely populated urban area. Terrorists could achieve this by acquiring an intact nuclear weapon or by obtaining highly enriched uranium or plutonium and building a bomb themselves.

\section{The threat of nuclear terrorism}

There is clear evidence that some terrorist groups have been trying to obtain nuclear materials, primarily from the enormous stockpiles of the former Soviet Union. In December 1994 Czech police seized $4 \mathrm{~kg}$ of highly enriched uranium. During that same year German police seized more than $400 \mathrm{~g}$ of plutonium. ${ }^{6}$ In October 2001 Turkish police arrested two men with $1.16 \mathrm{~kg}$ of weapons grade uranium. ${ }^{7}$ Also in October 2001 the Russian Defence Ministry reported two recent incidents when terrorist groups attempted to break into Russian nuclear storage sties but were repulsed. ${ }^{8}$ Since 1993 the International Atomic Energy Agency has reported 175 cases of nuclear trafficking, 18 involving highly enriched uranium or plutonium. ${ }^{9}$ Even more alarming are reports that small fully built nuclear weapons are missing from the Russian arsenal. In 1996 the Russian general Alexander Lebed claimed that 40 of these so called suitcase weapons were unaccounted for. He subsequently retracted the claim but in a manner that failed to reassure many experts. ${ }^{8}$

Even before the attack on the World Trade Center, the threat of nuclear terrorism was well recognised by the US Department of Energy, which warned: "The most urgent unmet national security threat to the United States today is the danger that weapons of mass destruction or weapons useable material in Russia 
could be stolen and sold to terrorists or hostile nation states and used against American troops abroad or citizens at home."10

The efforts of the al-Qaeda network to obtain nuclear weapons or weapons grade nuclear materials are particularly worrying. Al-Qaeda agents have tried to buy uranium from South Africa, and have made repeated trips to three central Asian states to try to buy weapons grade material or complete nuclear weapons. ${ }^{9}$ Sultan Bashiruddin Mahmood, a leading Pakistani nuclear engineer, made repeated visits to the Taliban stronghold of Kandahar between 1998 and 2001, leading the Pakistan government to place him and two other nuclear scientists under house arrest. ${ }^{11}$ More recently there have been speculative reports that al-Qaeda has purchased 20 of the Russian suitcase weapons from Chechen sources for a reported $\$ 30 \mathrm{~m}$ plus two tonnes of opium. ${ }^{11}$ In addition, Russian nuclear experts have raised concerns that terrorists could gain control of a Russian nuclear missile facility and initiate an attack against the United States using strategic nuclear missiles (B Blair, remarks delivered to National Press Club, 14 Nov 2001).

\section{The potential impact of a major nuclear attack}

Using the CATS (Consequences Assessment Tool Set) software created by the US Federal Emergency Management Agency and the Defense Threat Reduction Agency, we have calculated the expected casualties from a 12.5 kiloton nuclear explosion at ground level in New York City. We placed the explosion in the port area to reflect concerns that a nuclear device could most easily enter a US city smuggled in a commercial cargo container. The blast and thermal effects of such an explosion would kill 52000 people immediately, and direct radiation would cause 44000 cases of radiation sickness, of which 10000 would be fatal. Radiation from fallout would kill another 200000 people and cause several hundred thousand additional cases of radiation sickness. ${ }^{12}$

In the wake of such an attack the ability to aid survivors would be very limited. About 1000 hospital beds would be destroyed by the blast, and 8700 more would be in areas with radiation exposures high enough to cause radiation sickness. ${ }^{12}$ The remaining local medical facilities would quickly be overwhelmed, and even with advance preparation outside help would be delayed. After the 1995 earthquake in Kobe, Japan, in which 6500 died and 34900 were injured, there were long delays before outside medical assistance arrived, ${ }^{13}$ and this disaster had few of the complicating factors that would accompany a nuclear attack with extensive radioactive contamination.

\section{Security and prevention}

Security measures to prevent nuclear attacks must be continued, but we cannot rely on efforts to block terrorists from detonating nuclear devices. More effort must be directed at preventing their acquiring nuclear weapons in the first place. The large Russian arsenal contains tens of thousands of tactical nuclear warheads and 603 metric tonnes of weapons grade nuclear material stored at 53 different sites. ${ }^{14}$ Although the

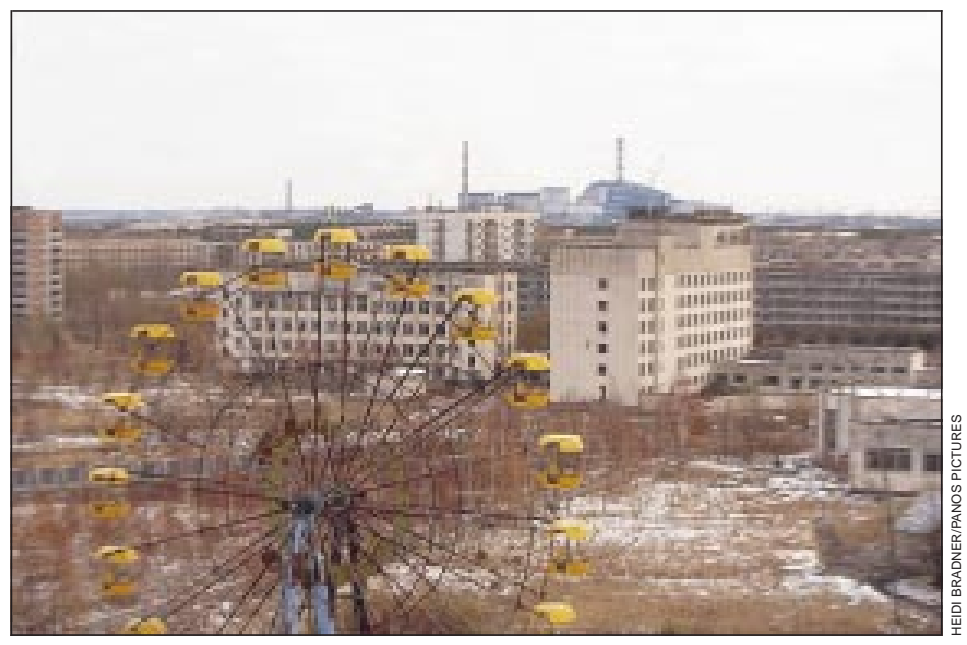

Pripyat, city of 48000 before the Chernobyl disaster, remains deserted 16 years later, providing a stark warning of the vulnerability of nuclear power stations and the potential impact of a nuclear terrorist attack

United States is currently spending over $\$ 900 \mathrm{~m}$ annually to try to secure these stockpiles, ${ }^{15}$ this is less than a seventh of the amount spent annually trying to develop a national missile defence system. The United States and other Western states urgently need to expand their efforts to help the Russian government secure these nuclear weapons and materials.

Increased attention must be directed at the dangers posed by Pakistan's and India's newly acquired nuclear arsenals and the possible danger of further nuclear proliferation. The Non-Proliferation Treaty should be vigorously supported and the Comprehensive Test Ban Treaty brought into force (see box).

\section{Conclusion}

As long as there are stockpiles of nuclear weapons in the world, the possibility of nuclear terrorism remains. Ultimately, the only way to eliminate this danger is to eliminate these weapons and establish strict international control of all fissile materials that could be used to make new weapons. In the international medical community many medical associations have joined Physicians for Social Responsibility in the United States and International Physicians for the Prevention of Nuclear War in calling for the abolition of nuclear

\section{Preventing nuclear proliferation}

The Non-Proliferation Treaty remains a cornerstone of efforts to prevent the spread of nuclear weapons. Its effectiveness is substantially undermined, however, by the refusal of the existing nuclear weapons states to fulfil their obligations under article VI to move to the complete elimination of their nuclear weapons. Similarly, the Comprehensive Test Ban Treaty could play an important role in preventing additional countries from acquiring nuclear weapons, but the refusal of the United States and several other actual or potential nuclear weapons states to ratify the treaty prevents it from coming into force. Further information is available on the websites of the Physicians for Social Responsibility (www.psr.org) and the International Physicians for the Prevention of Nuclear War (www.ippnw.org). 
weapons. ${ }^{16}$ Achieving this goal must be among the most urgent of all global public health priorities.

Competing interests: None declared.

1 Details of nuclear power left open. Guardian 24 Oct 2001 (www.guardian.co.uk/uslatest/story/0,1282,-1260475,00.html).

2 Tiwari J. Vulnerability of US nuclear power plants to terrorist attack and internal sabotage. Washington, DC: PSR Center for Global Security and Health, 2001.

3 Orrick DN. Differing professional opinion. Washington, DC: Nuclear Regulatory Commission, 1999

4 Muirhead CR. Cancer after nuclear incidents. Occup Enwiron Med 2001;58:482.

5 Finley NC, Aldrich DC, Daniel SL, Ericson DM, Henning-Sachs C, Kaestner PC, et al. Transportation of radionuclides in urban environs: draft environmental assessment (SAND79-0369, NUREG/CR-0743). Albuquerque, NM: Sandia National Laboratories, 1980.

6 Allison GT, Cote OR Jr, Falkenwrath RA, Miller SE. Avoiding nuclear anarchy. Cambridge, MA: Center for Science and International Affairs, Harvard University, 1996
7 Turkish police detain suspects selling uranium. Reuters 6 Nov 2001

8 Allison GT. Could worse be yet to come? Economist 1 Nov 2001.

9 International Atomic Energy Agency. Calculating the new global nuclear terrorism threat [press release]. 1 Nov 2001. www.iaea.org/worldatom/ Press/P release/2001/nt pressrelease.shtml (accessed 15 Jan 2002).

10 US Department of Energy. Task force report: a report card on the Department of Energy's non-proliferation programs with Russia. Washington, DC: DOE, 2001.

11 Kluger J. Osama's nuclear quest. Time 12 Nov 2001:38-40.

12 Helfand I, Furrow L, Tiwari J. Projected casualties from a terrorist nuclear explosion in a large urban area. Clinmed/20022010001 (11 Jan 2002). http://clinmed.netprints.org/cgi/content/full/2002010001v1

13 Tanaka K. The Kobe earthquake: the system response: a disaster report from Japan. Eur J Emergency Med 1996;3:263-9.

14 US Department of Energy. Material protection, control and accounting program, strategic plan. Washington, DC: DOE, 2001.

15 Tiwari J. The cooperative threat reduction program:essential for U.S. and global security. Washington, DC: PSR Center for Global Security and Health, 2001 .

16 Forrow L, Sidel VW. Medicine and nuclear war: from Hiroshima to mutual assured destruction to Abolition 2000. JAMA 1998;280: 456-61.

\title{
Commentary: The myth of nuclear deterrence in south Asia
}

\author{
Zulfiqar A Bhutta, Samiran Nundy
}

Aga Khan

University, Karachi, Pakistan

Zulfigar A Bhutta

Husein Lalji Dewraj

professor of

paediatrics

Sir Ganga Ram Hospital, New

Delhi, India

Samiran Nundy

consultant

gastrointestinal

surgeon

Correspondence to:

Z A Bhutta

zulfiqar.bhutta@

aku.edu
It is almost four years since India and Pakistan conducted their first tit for tat nuclear tests. Since then the development of nuclear weapons in both countries has proceeded steadily. ${ }^{1}$ Today India and Pakistan are believed to have nuclear arsenals and delivery systems capable of destroying all the major cities and industrial centres of both countries.

The protagonists of nuclear weapons in India and Pakistan claim that these weapons act as a deterrent against conventional armed conflict. But events in the past three years have put paid to this notion. In 1999 a major conflict erupted in Kargil, Kashmir, and the continued fighting in Kashmir has recently culminated in an unprecedented military stand off.

The current round of hostilities between India and Pakistan is due to several factors. These include the devastating effects of US attacks on al-Qaeda operatives in Afghanistan and their subsequent dispersion; tentative moves towards reining in religious extremists in Pakistan; terrorist attacks on the Indian parliament; and local political considerations in India, such as the forthcoming elections in Uttar Pradesh. The usual rhetoric has been taken to new heights by irresponsible bluster about first strikes, counterstrikes, and potential victory by one side or the other in a nuclear exchange. ${ }^{2}$

It is highly debatable if the acquisition of nuclear weapons by India and Pakistan has increased security in the south Asian tinderbox. India and Pakistan do not possess sophisticated nuclear control systems, nor do they share details of their nuclear capacity. The lengthy border between the countries makes it impossible to install early warning systems. As Helfand et al indicate, evidence of attempts by al-Qaeda terrorists to obtain nuclear weapons or materials and the potential of nuclear sabotage have placed the nuclear arsenals of both countries on an entirely different level of security watch.

The costs of developing and maintaining expensive arsenals in the context of extreme poverty and poor social indicators in these countries must also be emphasised. Many of the roots of the growth of

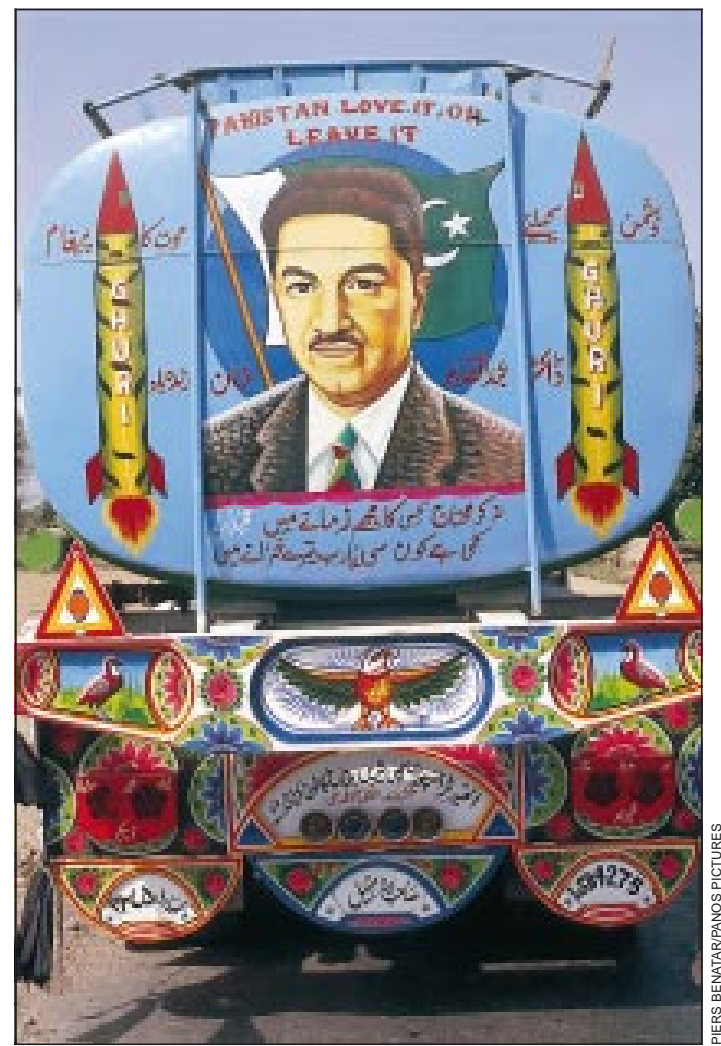

Promoting nuclear weapons as a source of national prestige is misguided and dangerous

militancy and terrorism lie in poverty and social deprivation (which have been exacerbated by the recent conflicts). Between 1944 and 1996 the United States spent $\$ 5.5$ trillion on nuclear weapons. ${ }^{3}$ The deployment of such colossal resources on nuclear arsenals seems inexcusable when viewed against the huge needs for human development and child health in developing countries. The incongruity of spending scarce resources on nuclear weapons is especially stark in south Asia. Reddy has stated that "the annual 
demands of weaponisation (in India) will finance 25\% of the yearly incremental costs of sending every Indian child to school." The opportunity costs of developing and maintaining nuclear arsenals must also be weighed against the devastation a nuclear holocaust would bring in its wake. ${ }^{56}$

The horrifying possibility of nuclear conflagration between India and Pakistan is of real and immediate concern. The anguish of families witnessing the severance of the last land link between the countries speaks volumes about their common history, heritage, and culture. Having brought the "Doomsday clock" forward, politicians, who do not speak for the largely disenfranchised masses, must publicly forsake the use of nuclear weapons and resume a political dialogue. Let sanity prevail.

1 Bidwai P, Vanaik A. South Asia on a short fuse: nuclear politics and the future of global disarmament. Karachi: Oxford, 2000.

2 "We could take a strike and survive: Pakistan won't". Fernandes. Hindustan Times 30 Dec 2001. (http://www.hindustantimes.com/nonfram/170102/ Archive.asp)

3 Schwartz SI. Atomic audit: the costs and consequences of US nuclear weapons since 1940. Washington DC: Brookings Institution, 1998.

4 Reddy CR. Wages of Armageddon. III. The Hindu 2 Sep 1998;Sect Opinion:12 ( $\mathrm{col} \mathrm{c})$.

5 Ramana MV. Bombing Bombay? Effects of nuclear weapons and a case study of a hypothetical explosion. Cambridge, MA: International Physicians for the Prevention of Nuclear War, 1999.

6 Naim SR. "Aadhi Raat Ke Baad" (after midnight). In: Cohen SP, ed. Nuclear proliferation in south Asia: prospects for arms control. Boulder, CO: Westview Press, 1991.

\title{
Commentary: The psychology of terrorists
}

\author{
Karen Colvard
}

The attacks on 11 September 2001 on the World Trade Center and the Pentagon thrust terrorism into the news again. The worldwide terrorist threats in the 1980s and early 1990s stimulated a wave of research on political violence, the conclusions of which are in danger of being ignored.

Terrorist groups are not usually composed of violent people, but people who choose to use violence as a tool to what they see as a reasonable end. ${ }^{1}$ Violence can be part of a rational strategy, with calculable costs and benefits, used as part of a moral commitment to a cause. ${ }^{2}$ Terrorists may pursue this cause with a sense of loyalty, selflessness, and righteousness thatwith other consequences-we might find admirable. The people who choose violence are usually fairly ordinary people in extraordinary groups, and we should look at the psychology of group processes rather than at individual psychopathology to understand their behaviour.

There are aspects of terrorists' backgrounds that can be compared to those of members of gangs and religious cults, where a search for identity through group membership facilitates the adoption of radical thinking. Accounts of how people become affiliated with violent groups often show more details about friendship and courtship than political grievance. ${ }^{4}$ Ideology can becomes a testing ground for belonging, demonstrating commitment to the group's chosen cause. ${ }^{5}$ Casting their cause as a "war" has been important to terrorists, who seek to have their commitment verified through equivalence with military confrontation. ${ }^{5}$

Although terrorists usually have only scant resources, they achieve an impact far beyond the physical damage they do. The media, whose participation is essential to transmit the danger to a wider audience than the one that is directly harmed, can inflate a threat into a crisis. The "mass sociogenic illness" after the anthrax scare in the United States is a good example. ${ }^{6}$ The Rand Corporation's senior adviser on terrorism has summarised terrorism as a "a lot of people watching, not a lot of people dead," although he also predicted, over 10 years ago, a growth in large scale, indiscriminate violence. ${ }^{7}$
Attempts to defeat terrorism with military might can be more dangerous to the government than to the terrorists, as its legitimacy is eroded, its citizens are required to sacrifice their own rights, and its enemies are multiplied. A quarter century of restrictions and retaliation has not lessened the threat to Israel from violent Palestinian groups, and questions from human rights organisations on the legality of that response have been damaging. A nation's best response to violence by small groups may often be to do nothing more than what the same violation would provoke if it were a criminal act without political resonance.

Violent groups are usually embedded within a network of psychological and ideological legitimacy, which gives them both material and moral support. ${ }^{78}$ Members of the ETA movement in Spain, for example, have been described as embodying the "Basque ideal." To their sympathisers, the violent group is competing for legitimacy with the law and the authority of the state. The revelation that the Spanish government sponsored terror squads against ETA operatives in the 1980 s enhanced sympathy for them, although their increasingly indiscriminate and savage actions have eroded it. Violence by either side can tip the balance of public opinion, and any government should consider carefully before implementing a brutal response or unfair retaliation that could weaken its moral position and diminish its support.

1 Kramer M. The moral logic of Hizballah. In: Reich W, ed. The origins of terrorism. Cambridge: Cambridge University Press, 1990:131-57.

2 Crenshaw M. The logic of terrorism. In: Reich W, ed. The origins of terror ism. Cambridge: Cambridge University Press, 1990:7-24.

3 Sprinzak E. The ascendance of Israel's radical right. New York: Oxford University Press, 1991.

4 Della Porta D. Life histories analysis of social movement activists. In Diani M, Eyerman R, eds. Studying collective action. London: Sage, 1992: 168-93

5 Powers T. Diana: the making of a terrorist. Boston: Houghton Mifflin, 1971

6 Wessely S, Hyams KC, Bartholomew R. Psychological implications of chemical and biological weapons. BMJ 2001;323:878-9.

7 McCauley C. Terrorism research and public policy: an overview. In McCauley C, ed. Terrorism research and public policy. London: Frank Cass, 1991:126-144.

8 Zulaika J. Basque nationalism: metaphor and sacrament. Reno: University of Nevada Press, 1988: xxii.
H F Guggenheim Foundation, 527 Madison Avenue, New York, NY 10022-4304, USA Karen Colvard senior program officer Kjcolvard@aol.com 